Article

\title{
Using Best Worst Method for Sustainable Park and Ride Facility Location
}

\author{
Jairo Ortega ${ }^{1, *(\mathbb{D})}$, Sarbast Moslem ${ }^{1} \mathbb{D}$, János Tóth ${ }^{1}$, Tamás Péter ${ }^{2}$, Juan Palaguachi ${ }^{3} \mathbb{D}$ \\ and Mario Paguay ${ }^{3}$ (i)
}

1 Department of Transport Technology and Economics, Faculty of Transportation Engineering and Vehicle Engineering, Budapest University of Technology and Economics, Múegyetem rkp. 3, 1111 Budapest, Hungary; moslem.sarbast@mail.bme.hu (S.M.); toth.janos@mail.bme.hu (J.T.)

2 Department of Control for Transportation and Vehicle Systems, Faculty of Transportation Engineering and Vehicle Engineering, Budapest University of Technology and Economics, Múegyetem rkp. 3, 1111 Budapest, Hungary; peter.tamas@mail.bme.hu

3 Departamento de Química y Ciencias Exactas, Ingeniería en Logística y Transporte, Universidad Técnica Particular de Loja (UTPL), San Cayetano Alto S/N, Loja 110107, Ecuador; jppalaguachi@utpl.edu.ec (J.P.); mvpaguay@utpl.edu.ec (M.P.)

* Correspondence: ortega.jairo@mail.bme.hu

Received: 23 October 2020; Accepted: 30 November 2020; Published: 3 December 2020

check for updates

\begin{abstract}
The Park and Ride (P\&R) system is a set of facilities available to private vehicle users to transfer to public transportation in order to complete their journey. The location of the facilities is determined by the purpose for which they have been created, for example, to reduce traffic in the central business district (CBD), reduce pollution, or increase the use of public transportation. Thus, a set of six main criteria and 19 sub-criteria are considered that are particularly important for decision-makers about the location of $P \& R$ facilities in a city. In order to identify which criteria are relevant, a method belonging to the multiple criteria decision is needed. The central point of this study is to evaluate the problem of the location of the facilities of the P\&R system according to the point of view of the experts. For this aim, the Best Worst Method (BWM) is adopted to estimate the location of the facilities of the P\&R system. The questionnaire survey has been designed estimated by ten transport experts in the related field. The recently created BWM was conducted. The results highlighted that "accessibility of public transportation" is the most important aspect of the problem of the location of P\&R facilities. The results obtained provide greater accuracy in the location of facilities problem than the pure analytic hierarchy process method (AHP).
\end{abstract}

Keywords: Park and Ride; sustainable Park and Ride location; multi-criteria decision-making; Best Worst Method; transport planning

\section{Introduction}

A widely used tool that planners and transport authorities use for the sustainable promotion of mobility in a city, particularly the urban area, is well-known as the Sustainable Urban Mobility Plan (SUMP). Thus, local governments employ the SUMP and use it to guide mobility policies that promote safe, clean, and environmentally friendly transport modes [1,2]. Among the chapters that integrate a SUMP, there are parking policies such as the Park and Ride (P\&R) system, which provides an alternative for private vehicle users to change to a more sustainable transport mode and thus minimize the adverse effects of the private car in a central business district (CBD) [3,4]. The definition of the P\&R system is that private vehicle users make their journey to the $\mathrm{CBD}$ in the following manner: a part of the journey is traveled by a private vehicle, and then it is parked to change to public transport to complete the 
journey [5,6]. According to this definition, a P\&R system constitutes a type of transport that provides a modal transfer towards a more sustainable transport $[7,8]$. Thus, being a modal interchange point, the location of the set of facilities is the crucial point in the design and implementation of the P\&R. The study of planning the P\&R system includes a set of criteria and sub-criteria to choose which of them are the most relevant $[9,10]$.

The P\&R system is a modal interchange point between private vehicles and public transport. Therefore, the $\mathrm{P} \& \mathrm{R}$ system facilities' locations are close to the public transport stations (e.g., light rail transit (LRT), metro, bus); this definition of the location could lead to the P\&R system having a facility in each station. Nevertheless, this is not possible due to financial resources' investment, and results in an evident lack of planning because other transportation factors are not considered. Therefore, using this single concept is not sufficient to establish the locations of the facilities of the P\&R system. Instead, it involves a more complex study that includes a set of criteria and sub-criteria. These criteria and sub-criteria were established by the following authors: [11-13]. Table 1.

Table 1. Criteria and sub-criteria for Park and Ride (P\&R) location.

\begin{tabular}{|c|c|}
\hline Criteria & Sub Criteria \\
\hline “Distance" & $\begin{array}{l}\text { "Distance from the zones to the P\&R system". } \\
\text { "Distance from P\&R system to central business district". }\end{array}$ \\
\hline "Traffic conditions on the route (origin-destination)" & $\begin{array}{l}\text { "Time of travel by private car". } \\
\text { "Time of travel by public transport". } \\
\text { "Time of travel by P\&R system". }\end{array}$ \\
\hline "Accessibility of public transport". & $\begin{array}{l}\text { "Frequency of public transport operations". } \\
\text { "Transfer time from P\&R to public transport stop". } \\
\text { "The distance of the P\&R from the nearest public transport stop". }\end{array}$ \\
\hline "Transport aspects". & $\begin{array}{l}\text { "Reduction of trips by private car in CBD". } \\
\text { "Increase of demand by public transport in CBD". } \\
\text { "Number of public transport connections available". } \\
\text { "Demand for parking at a P\&R system". }\end{array}$ \\
\hline "Economic" & $\begin{array}{l}\text { "Cost of implementation for the project". } \\
\text { "Cost of land use". } \\
\text { "Cost of the implementation of the telecommunication infrastructure". } \\
\text { "Total cost of investment maintenance". }\end{array}$ \\
\hline "Environmental" & $\begin{array}{c}\text { "COO} 2 \text { reduction". } \\
\text { "Noise reduction". } \\
\text { "Area occupied by existing green areas". }\end{array}$ \\
\hline
\end{tabular}

Table 1 shows the six main criteria and 19 sub-criteria that provide a detailed study of the P\&R system's facilities' positions. Ortega et al. [14] conducted their study using the analytical hierarchy and fuzzy triangle set process method, in which the public transportation accessibility criteria are the most significant when establishing the location of P\&R system facilities. This article uses a novel method with the same set of criteria, called the Best Worst Method to verify whether the public transportation accessibility criteria are still predominant.

This article is part of a project where the authors work to investigate a P\&R system and its different variables; thus, the authors have already made previous publications as part of an integrated analysis of P\&R [15-17]. Consequently, transport specialists have started to use multi-criteria decision-making applications (MCDM) to provide solutions to issues and increase the quality for citizens through transport initiatives. According to the literature that the authors reviewed, there are no articles that have developed a study of the locations of facilities of a P\&R system using the Best Worst Method in an emerging country, and that includes an elaborated list of criteria.

The article is written as follows: Section 2 contains the theoretical documentation used to study the MCDM methods, and the location of the P\&R. Section 3 exposes in depth the study's approach. Section 4 presents a case study from a city called Cuenca in Ecuador. Section 5 applies the method developed. Section 6 discusses and analyzes the results obtained by applying the methodology. In the conclusion section, the contributions are discussed. 


\section{Literature Review}

The literature review in this article presents the methods that the researchers have employed for the location of $P \& R$, followed by the description of the multi-criteria methods, in particular the BWM, used in this study.

Private vehicles have produced undesirable effects on the CBDs of cities; these effects are widely known as traffic and pollution. Researchers concerned about this issue have made several proposals to local governments to mitigate these problems. The majority of approaches have been a complete switch from private vehicles to a more friendly transport mode (e.g., pedestrians, bicycles, public transport) [18-20]. However, an alternative should also exist for inhabitants who own a private vehicle and live outside the urban area, and have limited or no connection to public transport services. This alternative is called the $P \& R$ system. An essential component of planning a $P \& R$ system is the location of each facility. Thus, researchers and transport planners have proposed methods and methodologies based on a set of parameters; however, the order of importance, or which ones should be considered when planning the P\&R system, are uncertain. Therefore, the literature describes a set of variables studied by researchers and planners concerning facilities' locations in the P\&R.

The location of the facility of a P\&R system is established through a set of parameters, such as the capacity, which refers to the number of required spaces that can be located in the facility of the P\&R system [21]. Besides, as mentioned previously, the second portion of the P\&R system's journey is made by public transport, which leads to the study of the combination of the P\&R system with public transport and the parameters such as demand, accessibility, and travel times. Thus, some articles have analyzed the interaction of the $P \& R$ with the public transport system's components. The parameters measured in a transport system such as the P\&R system are demand, travel time, and accessibility [22-24]. Besides, the first part of the journey that is made by private vehicle is essential to measure the traffic from the origin to the facility belonging to the P\&R system. The traffic depends on the location of the facility and the time of day that the measurement is taken, for instance, during high traffic hours or off-peak hours. The parameter of the demand in a Park and Ride system has been studied for some researchers that have used information systems (GIS) that have studied the demand of the catchment area [25-27]. In addition, Cavadas and Antunes [28] considered a model that includes the equations concerning the model choice and the function utilities. Du [29] studied the optimization of the location of the $P \& R$, which includes various transport modes, by the multimodal equilibrium approach. Furthermore, the P\&R system's location is closely associated with the characteristics of a transportation system, such as the potential number of users and connecting the facilities to the public transport stations [30].

The parameters in terms of the facilities' locations in the P\&R system that the researchers have taken into consideration are studied in the model of multi-criteria decision-making (MCDM), which has contributed solutions to several problems in the fields of transport and urban planning. Furthermore, mobility components are linked to MCDM models to find solutions to transport problems [31]. A multi-criteria method that is widely used is the AHP method, which is based on a set of criteria that experts choose for the solution of a problem. However, the AHP method is considered subjective because it involves an expert's expertise in choosing the appropriate solution [32].

Consequently, the AHP method, which is based on the criteria of perception, evaluation, correction, and choice of the decision by experts, leads to certain imperfections in the results, causing a certain lack of accuracy in the weighting of the criteria and resulting in outcomes that are contradictory to the real facts [33]. In order to solve these problems, AHP weighting vectors such as Pareto's have been used as an alternative [34]. The experts compared and even optimized the pairwise matrices using a real case, adding a sensitivity evaluation supported by a simulation approach and an analytical network process (ANP) [35-37]. The efficiency of the implemented model AHP varies with the scenario chosen by this approach and the kind of analysis it is most suited for.

The AHP has employed various mathematical and optimization models in order to obtain better levels of accuracy. A sensitivity analysis with the help of Monte Carlo Simulation is used [38-40]. In another integration model, the AHP method was used to integrate a model with the order of 
preference technique for similarity with the preference on ideal solution, in order to establish the efficiency of its methodology [41,42]. Besides, a hybrid model known as frequency ratio and a hybrid multi-criteria assessment (SMCE) were used to obtain more accurate results [43,44]. A combination of fuzzy theory and AHP is used to interpret imprecise metrics within mathematical decision-making operators in the fuzzy domain $[45,46]$. However, this data set is usually not accessible due to many factors that influence decision-making methods.

The ANP can be combined with the fuzzy theory to minimize the potential errors inherent in the decision-making system, making it a more realistic approach to experts' responses $[47,48]$. The P\&R system and MCDM methods have been combined in a few investigations. Research has been carried out to evaluate the facilities of $P \& R$, covering factors such as social, environmental, and economic aspects [49]. Szymon Fierek et al. [50] used multi-criteria to assess the P\&R location. The analysis involved 15 P\&R facilities, and planned the localities using the VISUM simulation method. The method known as the BWM helps minimize the pairwise comparisons (PCs) in the questionnaire survey [51,52]; the approach attempts to allow less peer-to-peer comparisons than the traditional method. Instead, the method is new, and it has not been used to study which criteria are relevant to the P\&R system's location.

According to the P\&R and MCDM literature, a study discrepancy can be explicitly stated on the subject suggested in this paper. In particular, there is a void in the implementation of advanced MCDM models in P\&R planning. This paper seeks to develop a combined model to help consensus decisions on the locations of P\&R facilities using the BWM framework. This research is also part of a project named the "Integrated Study of Parking and Ride Facilities for Sustainable Urban Mobility".

\section{Materials and Methods}

This section covers the components and materials used to conduct the methodology, including an explanation of how the survey was conducted, followed by a detailed explanation of the study and an explanation of the method used.

\subsection{Survey}

The survey was developed based on meetings and discussions held with transport planning experts to identify the most important criteria for implementing a collection of facilities in a P\&R system. The survey then took place in May 2020. The participants were selected from transport planning experts from the municipality and the university, who included six men and four women of various ages. The survey was filled out in 25 to $30 \mathrm{~min}$ per expert. In total, 25 elements of the P\&R systems were evaluated (as shown in Section 3.2) to analyze professionals' priorities and behaviors in support of the P\&R system.

\subsection{Design of Saaty Scale and Description Criteria}

Planning and selecting the criteria to be used or taken into consideration for the location of the P\&R system installations is one of the most important parts of the study, and subsequently, these criteria are ordered based on the standards of the 1-9 scale. One of the advantages of this scale is that it is simple to apply and also uses a scale of proportions. Besides, it is more accurate than other methods because it compares each indicator with the other. In the previous study, six main criteria and 19 sub-criteria were identified [14]. The components described in the introduction are explained in detail to cover each of them.

Table 2 shows the codification of each main criterion and also contains the description of the first level. Six criteria are the main criteria at this level (designated as level 1). These criteria have been assigned a code that ranges from C1 to C6. Thus, they can be easily identified in Figure 1. 
Table 2. Main criteria and description of the criteria of the P\&R location problem.

\begin{tabular}{ccc}
\hline Explanation & Description & Criteria Code \\
\hline "Distance" & $\begin{array}{c}\text { One of the key factors for the place of a facility in the P\&R is } \\
\text { the distance criterion. }\end{array}$ & C1 \\
\hline $\begin{array}{c}\text { "Traffic conditions on the route } \\
\text { (origin-destination)" }\end{array}$ & $\begin{array}{c}\text { The traffic from the origin to the destination at varying } \\
\text { hours of the day, merging two transport modes belonging to } \\
\text { the P\&R system (private car and public transport). }\end{array}$ & C2 \\
\hline "Accessibility of public transport". & $\begin{array}{c}\text { Represents the aspects related to the second portion of the } \\
\text { journey by the P\&R, which is by public transport. }\end{array}$ & C3 \\
\hline "Transport aspects". & $\begin{array}{c}\text { The P\&R system is considered a transport mode and } \\
\text { therefore involves the detailed study of aspects related to } \\
\text { transport planning. }\end{array}$ & C4 \\
\hline "Economic" & $\begin{array}{c}\text { Economic evaluation is a criterion used to determine the } \\
\text { feasibility of the project. }\end{array}$ & C5 \\
\hline "Environmental" & $\begin{array}{c}\text { In recent years, this criterion has become a significant } \\
\text { element for the implementation of a P\&R. }\end{array}$ & C6 \\
\hline
\end{tabular}

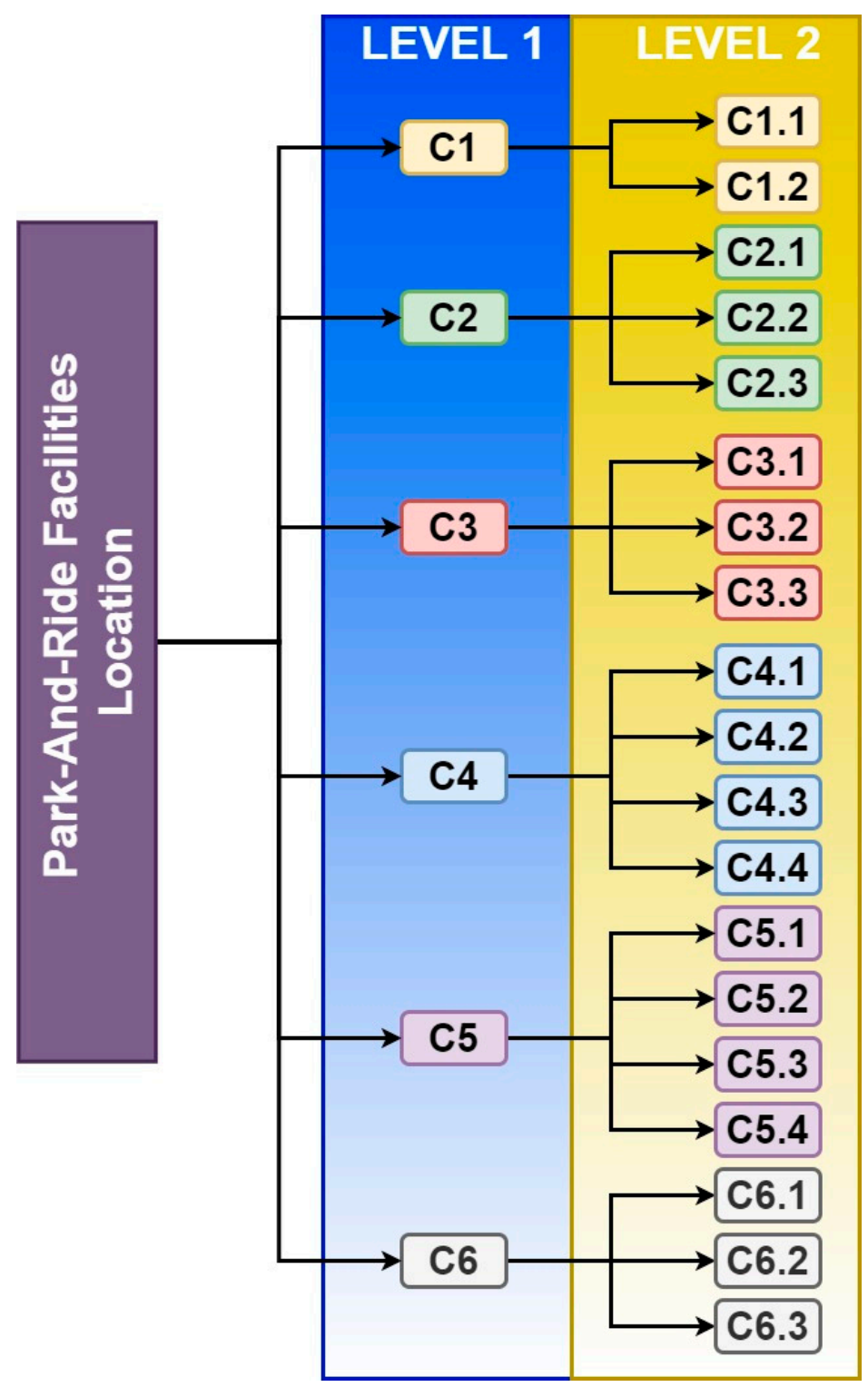

Figure 1. The hierarchical structure of $P \& R$ location. 
The second part of the construction of the Saaty scale concerns the second level, which is composed of 19 sub-criteria from the first level. Table 3 describes each one of them and provides a code that identifies which main criteria it belongs to, and further designates a sub-criterion, for example, the sub-criterion that belongs to criterion one is designated C1.2 C1.1. Thus, it is possible to identify them on level two of Figure 1.

Table 3. Sub-criteria and description of the sub-criteria of the P\&R location problem.

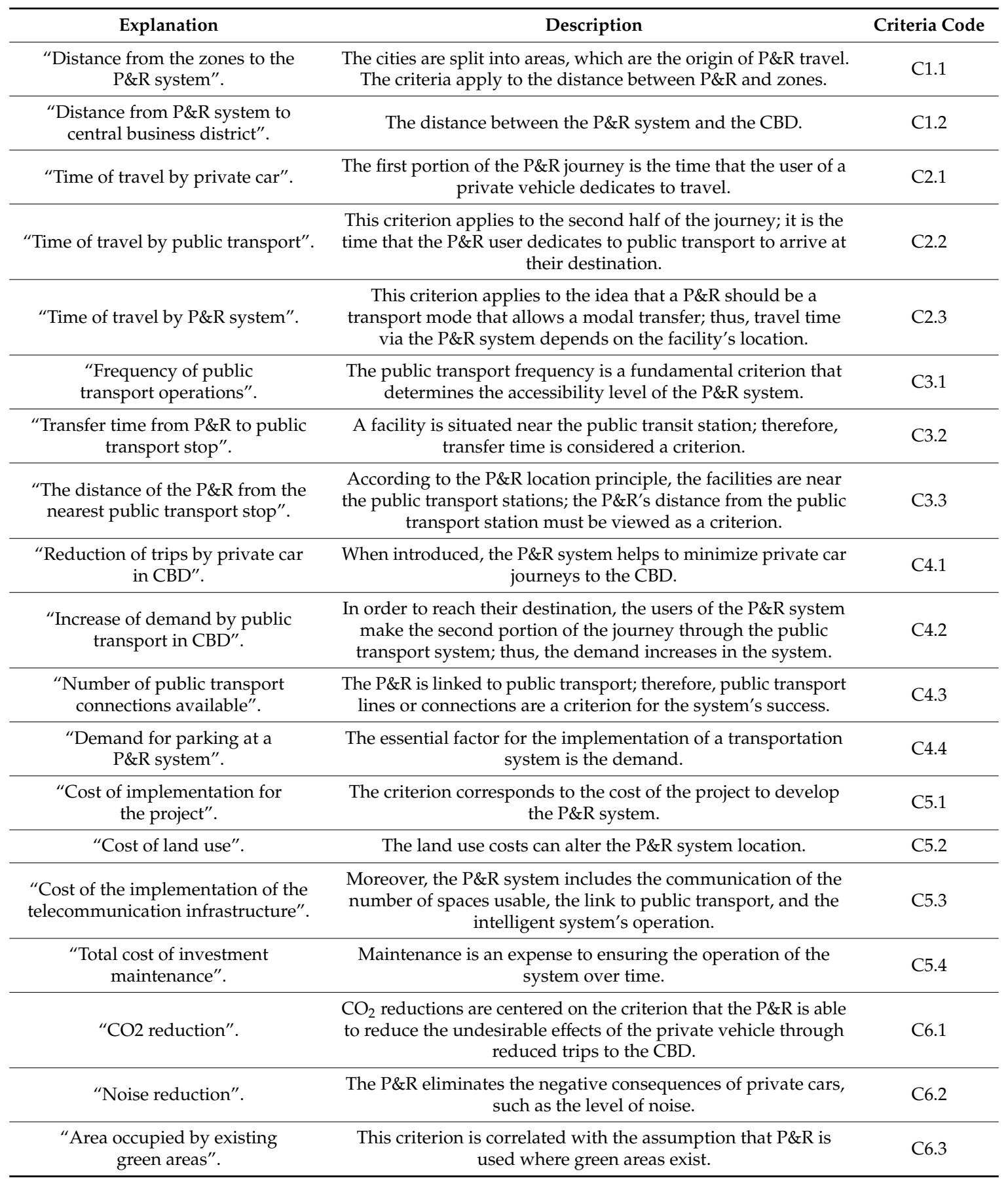

Furthermore, due to the better overview of experts, the P\&R location criteria were designed within a hierarchy due to the requirements of the hierarchical Best Worst Method used. The process is determined by the criteria' hierarchical structure, where pairwise comparisons between criteria in the same category of the decision criteria tree are chosen by the expert evaluators (see Figure 1). 


\subsection{Best Worst Method}

The Best Worst Method (BWM) has been applied in order to generate the weights in the criteria and sub-criteria while making less pairwise comparisons and providing a more consistent comparison process. The best or most important criterion or alternative is the most important criterion for decision-making, whereas the worst or least important criterion or alternative plays the opposite role [53,54]. BWM was developed as part of a wide variety of MCDM approaches. It is perceived as an efficient approach due to its data requirements, its well-structured, transparent, easy application, and its reliable results [55]. The critical difference between the BWM approach based on pair comparisons is its main framework depending on the most relevant and least important parameters [56]. The BWM's attractiveness derives from its benefits, including various features that promote estimation and interpretation-less pair comparisons than in other approaches, better reliability of measured weight coefficients, and performance accuracy. The main steps can be briefly presented in the following steps:

- Determining the criteria for decision-making;

- Defining the least important (worst) and most important (best) criteria;

- Defining the most important preference criterion (the best) over all other criteria;

- Defining the least important criterion (worst) of all the least important criteria;

- Checking coherence;

- Measurement of weight values.

We consider various elements $\left(e_{1}, e_{2}, \ldots, e_{n}\right)$ and then choose and compare the best element on the scale (designed from 1-9). This calculation gives the best element to others, and the adopted vector would be $V_{B}=\left(e_{B 1}, e_{B 2}, \ldots, e_{B n}\right)$, and obviously $e_{n n}=1$. However, the worst element compared to other vectors would be $V_{W}=\left(e_{1 W}, e_{2 W}, \ldots, e_{n W}\right)^{T}$ by using the same scale.

After deriving the optimal weight scores, the consistency has been checked through computing the consistency ratio from the following formula:

$$
C R=\frac{\xi^{*}}{\text { Consistency Index }}
$$

where Table 4 provides us with the consistency index values:

Table 4. Consistency index (CI) values.

\begin{tabular}{cccccccccc}
\hline $\boldsymbol{e}_{\boldsymbol{a} \boldsymbol{b}}$ & $\mathbf{1}$ & $\mathbf{2}$ & $\mathbf{3}$ & $\mathbf{4}$ & $\mathbf{5}$ & $\mathbf{6}$ & $\mathbf{7}$ & $\mathbf{8}$ & $\mathbf{9}$ \\
\hline Consistency Index $(\max \xi)$ & 0 & 0.44 & 1.0 & 1.63 & 2.3 & 3.0 & 3.73 & 4.47 & 5.23 \\
\hline
\end{tabular}

In order to achieve an optimum weight for all the elements, the maximum differences are specified as $\left|\frac{w_{B}}{w_{j}}-e_{B j}\right|$ and $\left|\frac{w_{j}}{w_{W}}-e_{j W}\right|$, and for all, $j$ is minimized. If we assumed a positive-sum for the weights, the following problem would be solved:

$$
\min \max _{j}\left\{\left|\frac{w_{B}}{w_{j}}-e_{B j}\right|,\left|\frac{w_{j}}{w_{W}}-e_{j W}\right|\right\}
$$

subject to (s.t.)

$$
\begin{gathered}
\sum_{j} b_{j}=1 \\
b_{j} \geq 0, \text { for all } j
\end{gathered}
$$

The conflict could be referred to in the following instance:

$\min \xi$ 
subject to (s.t.)

$$
\begin{gathered}
\left|\frac{w_{B}}{w_{j}}-e_{B j}\right| \leq \xi, \text { for all } j \\
\left|\frac{w_{j}}{w_{W}}-e_{j W}\right| \leq \xi, \text { for all } j \\
\sum_{j} b_{j}=1 \\
b_{j} \geq 0, \text { for all } j
\end{gathered}
$$

By solving this problem, we obtain the optimal weights and $\xi^{*}$.

\section{Case Study}

This research involves applying the method in a real case study; for this purpose, the Cuenca city in Ecuador has been chosen. Cuenca is a city located in the south of Ecuador that has developed two significant transport projects: the sustainable mobility plan and the implementing of a new transport system, LRT. As additional knowledge, Cuenca is made up of 15 urban areas, and each area is split into neighborhoods segregated by downtown roads. Besides this, UNESCO has classified the historic center as a World Heritage Site. The high level of congestion in the downtown area has become one of the issues. Several studies in the field of mobility were carried out by Orellana et al. [57]. The author made a significant contribution to the study on the impact of the public space, including its street networks and bike users' mobility. Hermida et al. [58] have also published research on the effect of the building design on mobility.

Nevertheless, few studies have been performed for users who come in a private car from outside the metropolitan area regularly and decide to travel to the city center in a more convenient transport mode like the LRT. For this issue, in a study developed by Ortega et al. [59,60], seven facilities were established through each facility capacity (designed from A to G). Figure 2 shows the $10 \mathrm{~km}$ LRT system, the urban areas, and the P\&R.

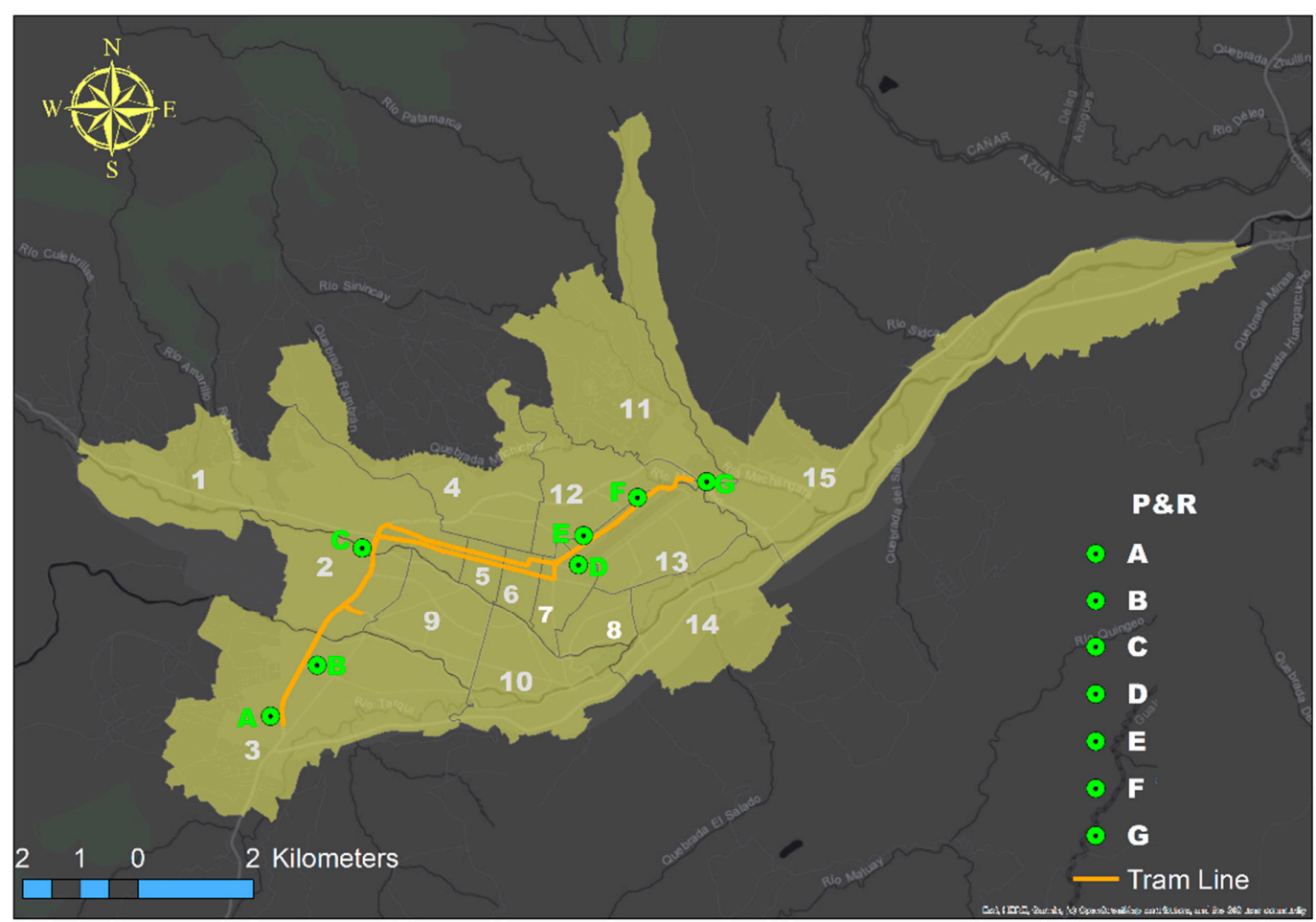

Figure 2. The Cuenca city is divided into zones, the P\&R system, and the LRT line. 


\section{Results}

The questions developed in the survey involve a first comparison of the main criteria belonging to level one, for example, comparing the relative value of the P\&R system facilities among "distance-C1" and "traffic conditions on the route (origin-destination) - C2".

Having obtained all the aggregated weights of the ten expert evaluators, PCs must be generated for all branches of the decision system, as shown below, according to the BWM method (Figures 3-9).

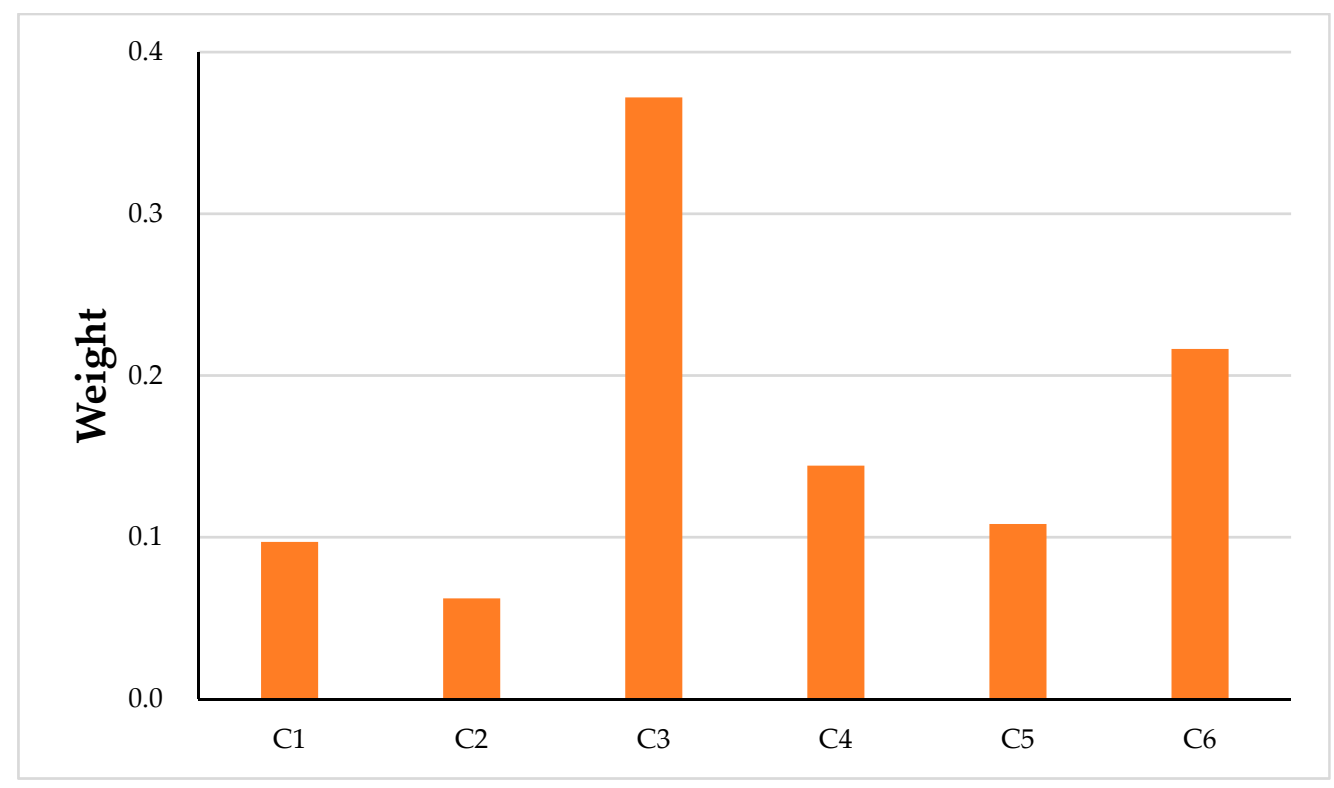

Figure 3. The aggregated weight scores for park and ride facilities' main criteria in level 1.

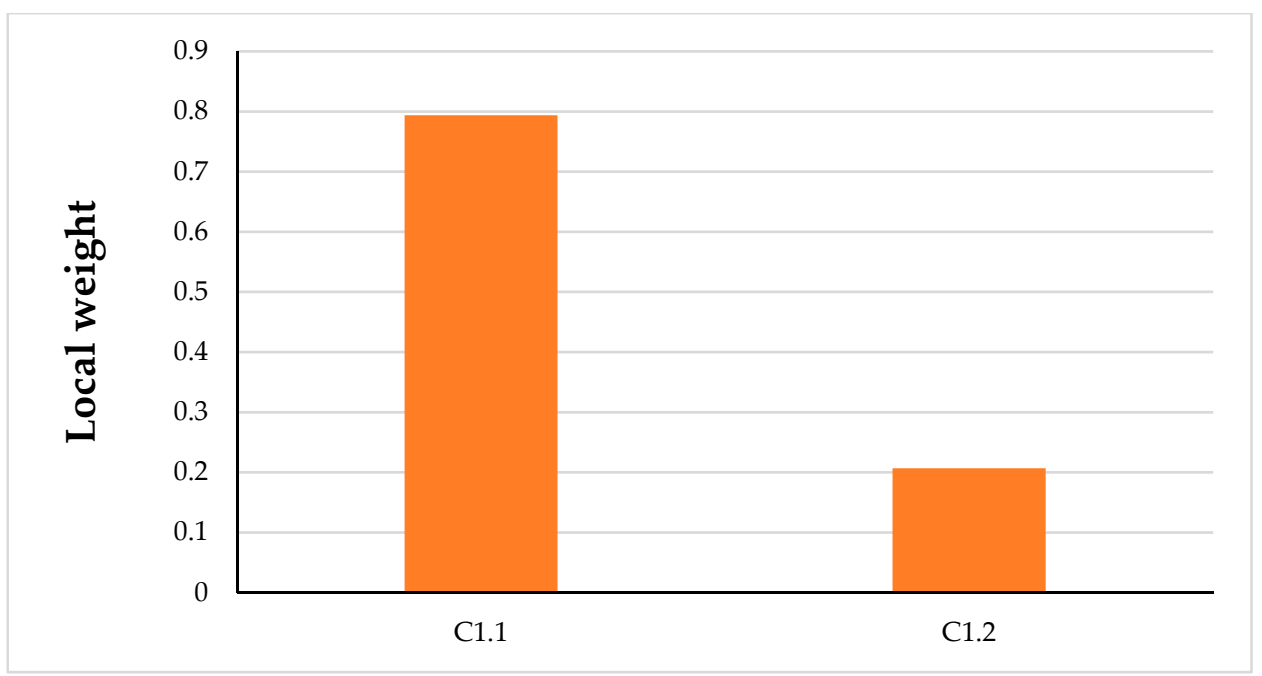

Figure 4. The final aggregated weight scores for "Distance" in level 2. 


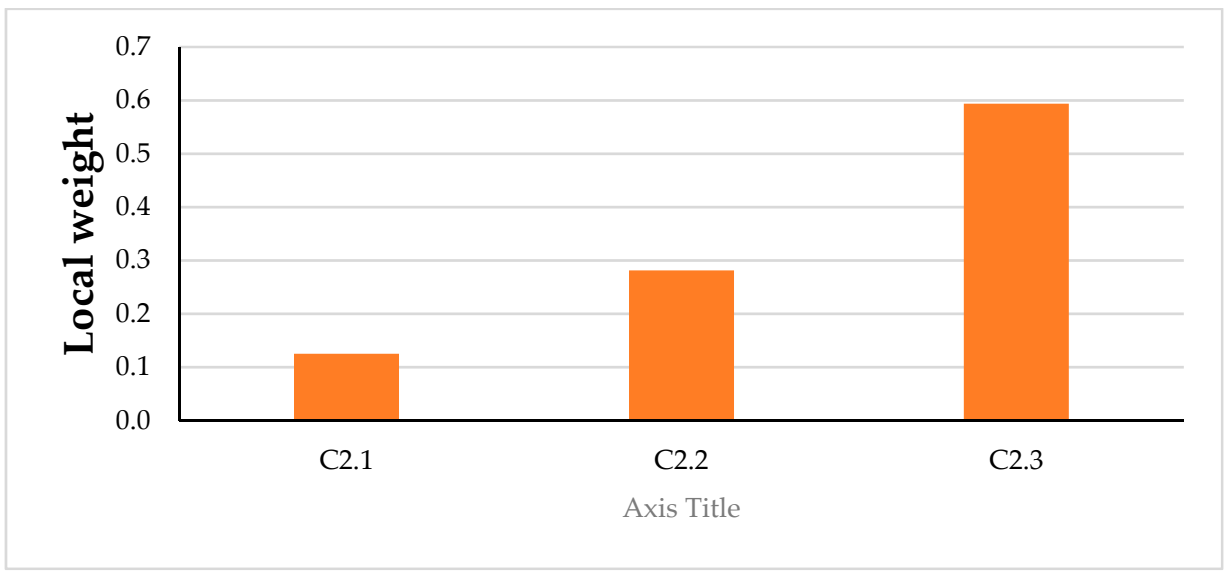

Figure 5. The final aggregated weight scores for "Traffic conditions on the route (origin-destination)" in level 2.

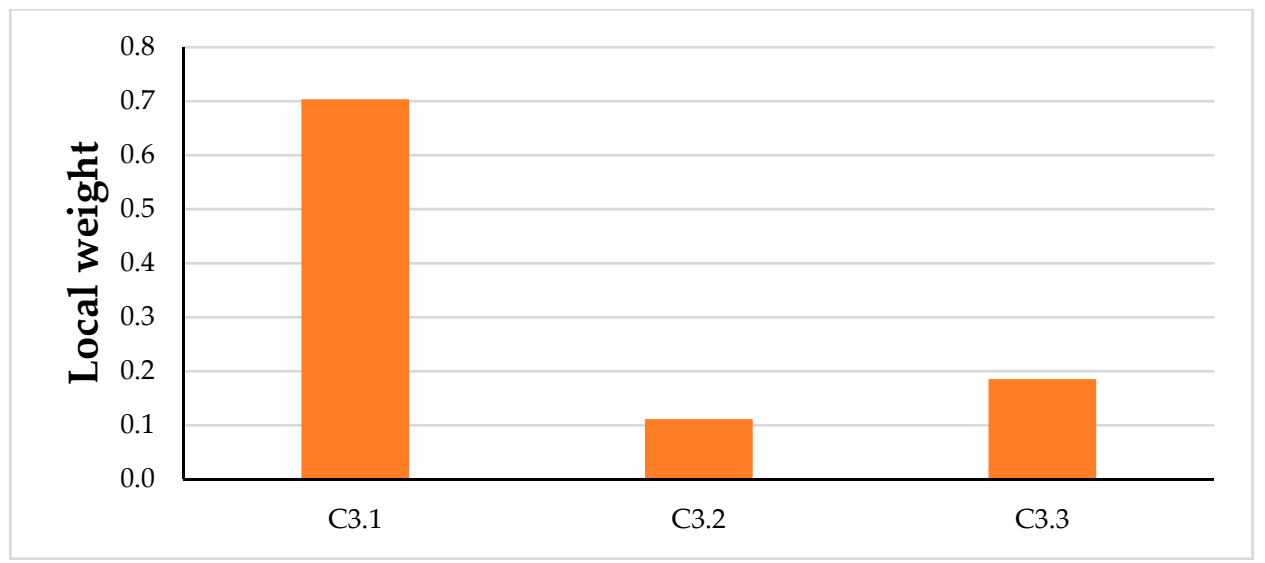

Figure 6. The final aggregated weight scores for "Accessibility of public transport" in level 2.

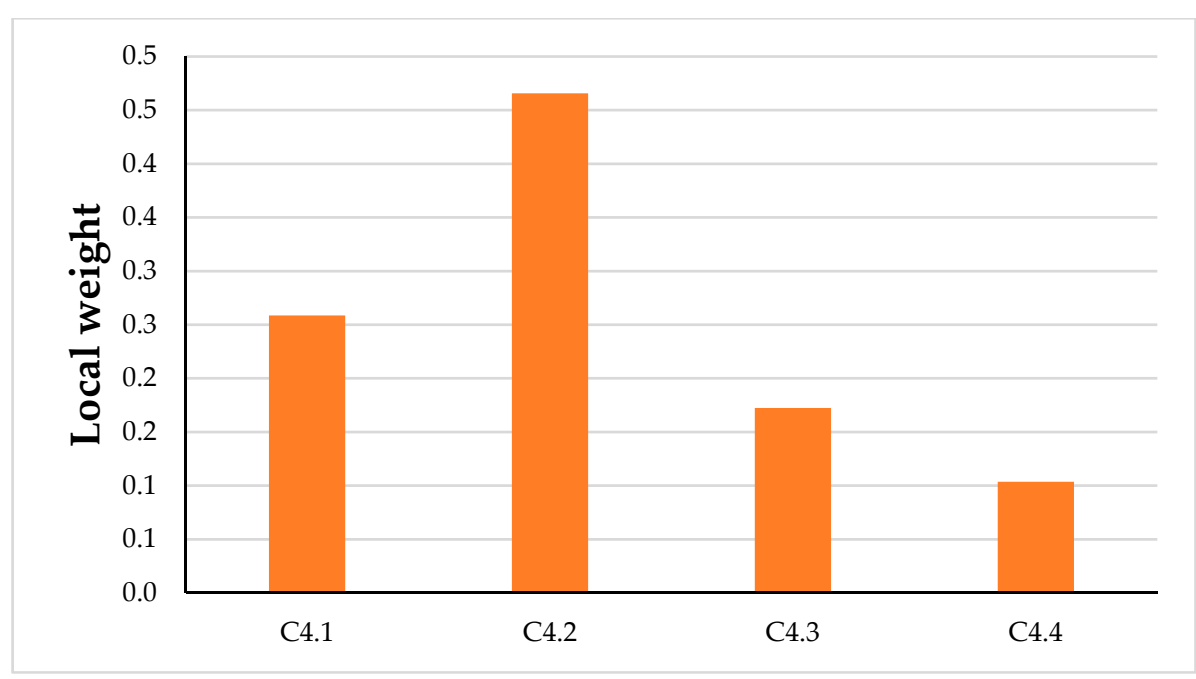

Figure 7. The final aggregated weight scores for "Transport aspects" in level 2. 


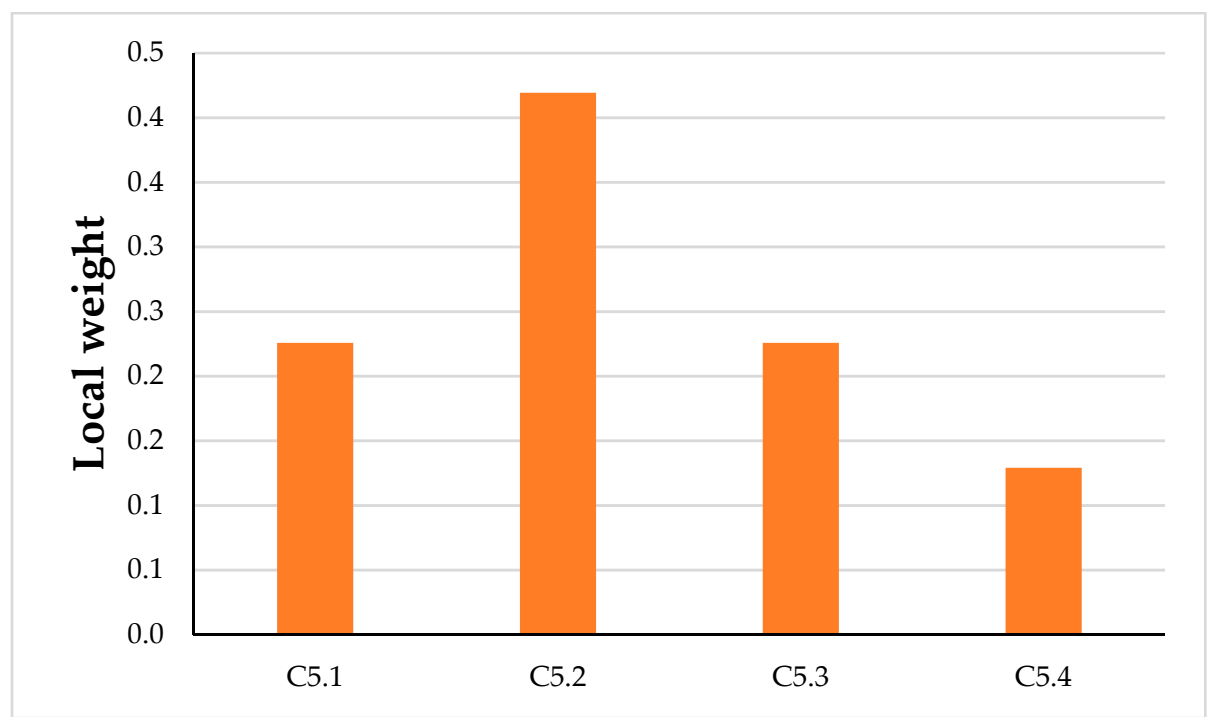

Figure 8. The final aggregated weight scores for "Economic" in level 2.

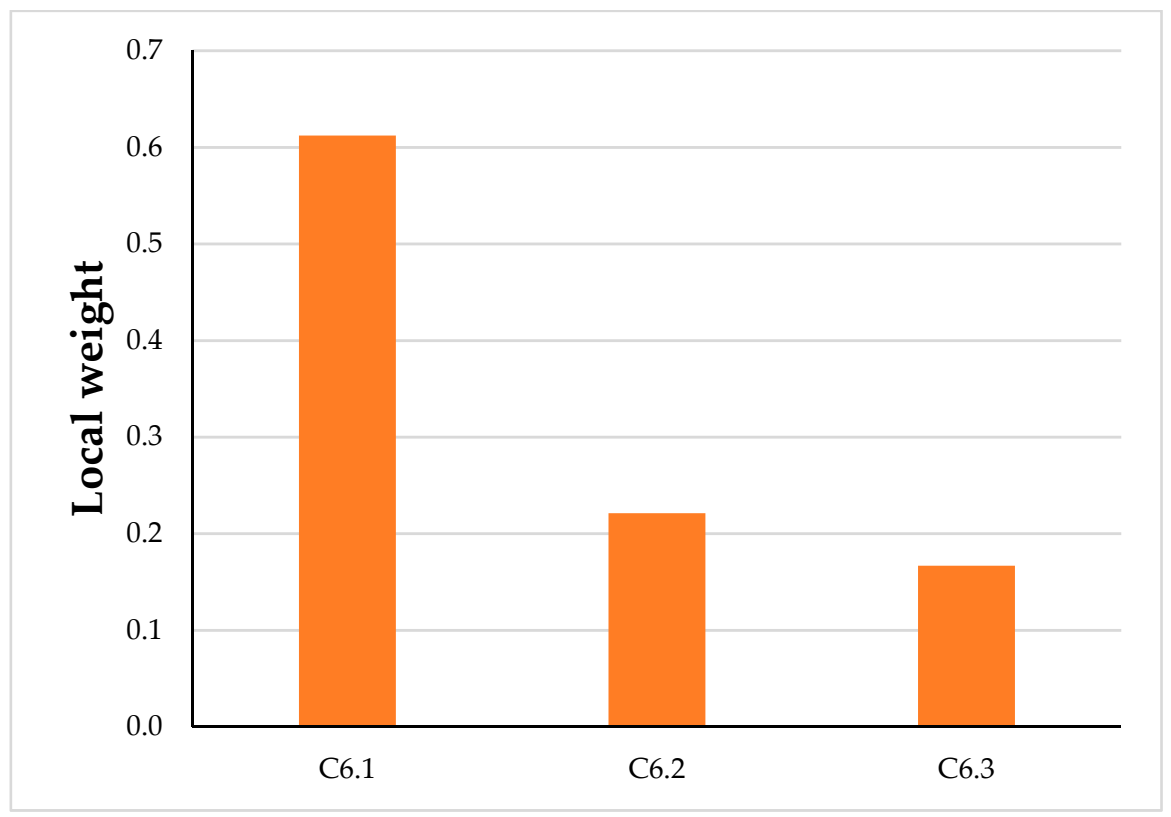

Figure 9. The final aggregated weight scores for "Environment" in level 2.

Afterward, the final weights of the criteria in the second level were computed by considering the relation with the main criteria in the first level. The higher the weight means the higher the significance attached to each criterion. The order of weights indicates a ranking of significance, which is strongly confirmed by expert evaluators in P\&R. Table 5 presents the priority order for the implementation of different criteria in the park and ride facilities. 
Table 5. The final aggregated weight scores for the park and ride facilities' sub-criteria in level 2.

\begin{tabular}{ccccc}
\hline Main Criteria & Sub-Criteria & Rank & Global Weight & Rank \\
\hline \multirow{2}{*}{ C1 } & C1.1 & 1 & 0.0771 & 3 \\
& C1.2 & 2 & 0.0201 & 15 \\
\hline \multirow{2}{*}{ C2 } & C2.1 & 3 & 0.0078 & 19 \\
& C2.2 & 2 & 0.0175 & 16 \\
C3 & C2.3 & 1 & 0.0369 & 10 \\
\hline \multirow{3}{*}{ C4 } & C3.1 & 1 & 0.2617 & 1 \\
& C3.2 & 3 & 0.0414 & 8 \\
& C3.3 & 2 & 0.0688 & 4 \\
\hline & C4.1 & 2 & 0.0373 & 9 \\
& C4.2 & 1 & 0.0671 & 5 \\
C5 & C4.3 & 3 & 0.0249 & 12 \\
& C4.4 & 4 & 0.0149 & 17 \\
\hline & C5.1 & 2 & 0.0246 & 13 \\
& C5.2 & 1 & 0.0454 & 7 \\
& C5.3 & 3 & 0.0244 & 14 \\
& C5.4 & 4 & 0.0140 & 18 \\
\hline & C6.1 & 1 & 0.1325 & 2 \\
& C6.2 & 2 & 0.0478 & 6 \\
& C6.3 & 3 & 0.0361 & 11 \\
\hline
\end{tabular}

\section{Discussion}

The surveys conducted with the transport planning staff of local municipalities and local universities about facilities' locations in the $P \& R$ system resulted in an essential valuation of all the factors that planners consider when locating a facility. This approach makes it possible to establish which criteria are considered to be most relevant.

The discussion section is divided into three categories to help readers to understand better. The first part refers to the level one of Figure 1 and explains the order of importance and the importance of considering all these criteria. The second part consists of a comparison between the sub-criteria belonging to the main criterion. Finally, the results of the second level are discussed, in which the 19 sub-criteria are ranked.

The first level in which the six criteria are listed is the order of relevance. The most significant is the criterion C3 of "accessibility to public transport". This is a very logical result because the second part of the trip is made by public transport in a P\&R system. Therefore, the accessibility of public transport is also the accessibility of the P\&R system. Next is criterion C6, which refers to the "environment"; this criterion is described in the literature review regarding the P\&R system used to reduce the car's undesirable effects in the central district. In order of priority, the following criterion is C4, which refers to those aspects of transportation where the P\&R system is introduced as part of the city's transportation network and interacts with other transportation systems. It refers to the fact that location is linked to public transportation connection, demand, and supply. The following criterion is the "economic", C5, whereby, like all transport projects, the economic part of developing the project depends on the location and feasibility of the project. The penultimate criterion is $\mathrm{C} 1$, which refers to the shortest or longest distance to the $\mathrm{P} \& \mathrm{R}$ system, although transport planners do not consider it of great importance because the first part of the journey is made in a private vehicle. The lowest criterion is $\mathrm{C} 2$, which refers to the route's traffic conditions, as the second part usually has a direct public transport line from the Park and Ride system to the destination; therefore, the traffic conditions for the location are not necessary.

The principal criterion contains several sub-criteria; for instance, criterion $\mathrm{C} 1$ is composed of two sub-criteria in which the "Distance of the zones to the P\&R system" is more relevant than the 
criterion "Distance from the P\&R system to the central business district". This is because the first part of the journey is made by private vehicles; thus, the distance the user is willing to travel in the first part of the trip is more relevant than the distance of the second part of the trip made by public transport. The following is concerning the second criterion, C2. Sub-criterion C2.3 is the most relevant and represents the total travel time through the P\&R system (private vehicle + parking time + bus time). In contrast, when comparing sub-criteria C2.1 and C2.2, the most relevant is travel time by public transport, which means that the hours of operation of public transport are relevant to ensuring the system's accessibility. Experts have determined that one of the most important aspects of the P\&R system concerns public transport. Regarding the sub-criteria belonging to the main criterion, C3, C3.1, "Frequency of public transport operations", is the most important because it ensures connectivity with the second part of the trip. This is followed by C3.3, "Distance of the P\&R from the nearest public transport stop". As described in the literature, it is one of the concepts of the location of the facilities that belong to the P\&R system; as a result of this, the sub-criterion C3.2 is associated with the transfer time. In terms of $\mathrm{C} 4$, the order of relevance of the sub-criteria is $\mathrm{C} 4.2$, wherein the demand for public transportation is increased due to the P\&R system's potential users. Next is C4.1. The reduction of private car trips is one of the P\&R system's objectives, and therefore is one of the most important components. C4.3 is the connection, and the number of lines for public transport available. C4.4 is the parking demand in the P\&R system. Criterion $\mathrm{C} 5$ refers to the economic part of the project, and sub-criterion C5.2, which is the cost of land use, depends on the project's economic viability, followed by C5.1 and C5.3 which refer to the economic part of the operation of the P\&R system. Sub-criteria C5.4 refers to the cost of implementation and maintenance. Further, the order of relevance of criterion $\mathrm{C} 6$ 's sub-criteria are pollution reduction, C6.1, followed by noise reduction, C6.2. These two sub-criteria refer to the undesirable effects of the private vehicle on the CBD that can be reduced by implementing a P\&R system, and finally, C6.3 refers to the expropriation of land used principally within green areas.

Level two of the hierarchy requires a comprehensive explanation and has been divided into three categories for better understanding (Figure 10)—most important, mid-level important and low-level important. For instance, most important $<6$, mid-level important 6-12, $>12$ low-level important. The most important is C3.1, which belongs to the "Frequency of public transport operations". It is considered by the experts to be fundamental to implement a P\&R system, which guarantees accessibility and connection to public transport, as the $\mathrm{P} \& \mathrm{R}$ system is an interchange point between the private vehicle and the public transport. Continuing with the order of importance and ranked second is criterion C6.1, which is one of the objectives clarified by the experts illustrating that the P\&R system is an instrument that reduces the contamination in the CBD. In the ranking approaching sixth place, there are the sub-criteria C1.1 and C3.3. These two sub-criteria refer to the distance from the origin to the facility in the P\&R system, and add to the facility's distance to the public transport station. They are followed by C4.2, which refers to demand, meaning that public transport demand from users of the P\&R system increases. C6.2 refers to the undesirable effects of private vehicles, such as noise. Following the intermediate level, criterion C5.2 refers to the cost of land use, in terms of expropriating or using the land to implement the P\&R system. This is followed by C3.2, which is the transfer time from the facility to the public transport station. This is followed by C4.1, which refers to the reduction of private vehicle trips in the CBD. They are followed by C2.3, which is the total travel time through the P\&R system. C6.3 refers to the land occupied by the P\&R system to be expropriated. C4.3 refers to the number of transit connections connected to the P\&R system. The following are the levels of the sub-criteria considered not relevant for implementing the P\&R system. Sub-criteria C5.1 and C5.3 refer to the economic costs of implementing the project. C1.2, C2.2 and C.4.4 refer to general transportation aspects, such as demand and travel time spent on public transportation, which is guaranteed due to its connection to or implementation of a public transport line. C5.4 refers to the cost of maintenance. C2.1 is the least important of all the criteria because it corresponds to the first part of the journey made by a P\&R system. 


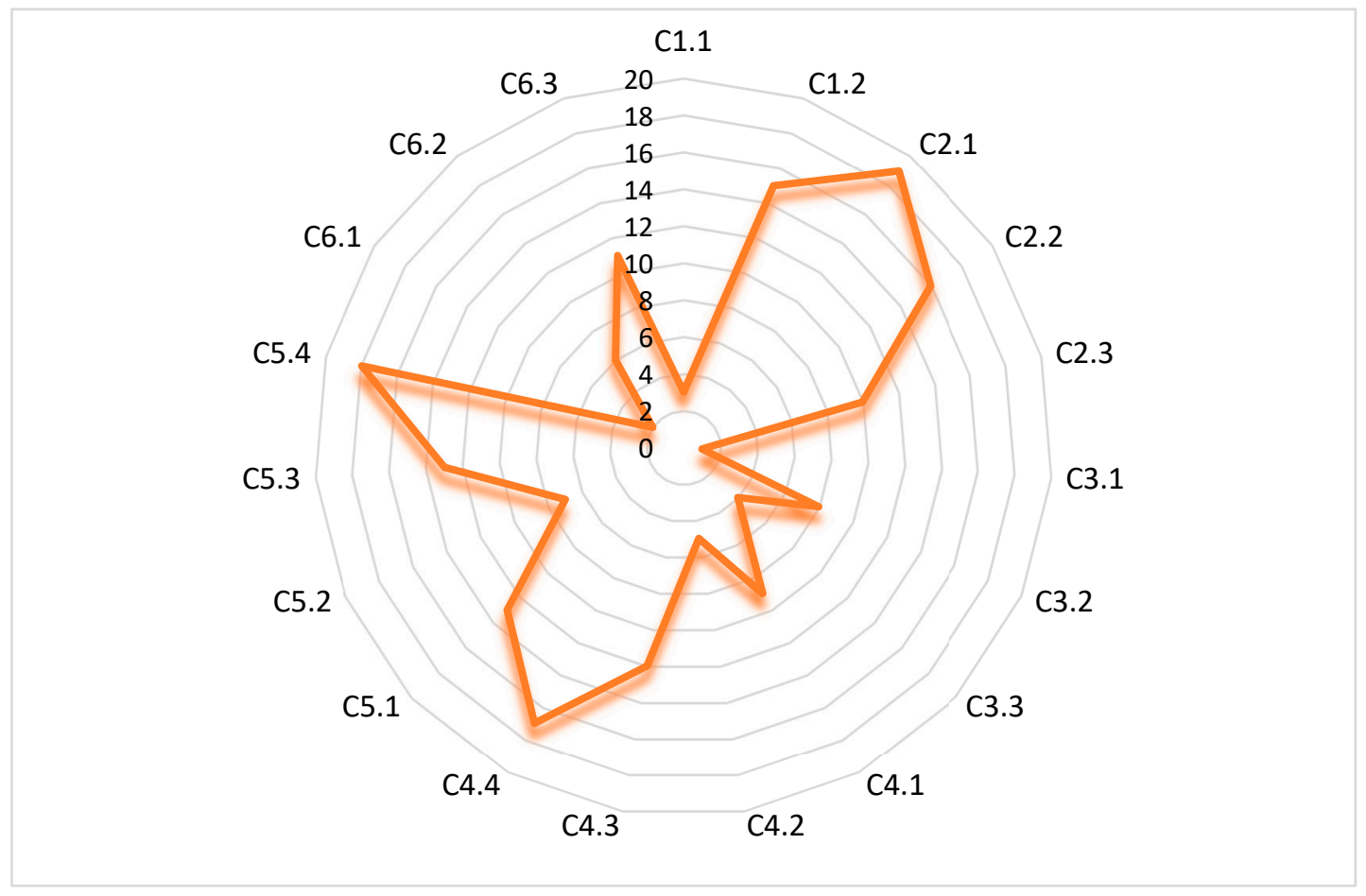

Figure 10. Priority ranking of sub-criteria.

The criteria value was adjusted to hold a near-one value also for total weight values. The sensitivity analysis was used at all levels, and the ranking adjustments were evaluated based on the ability of planners to define a criterion. Therefore, the planners selected the criteria according to their expertise in the development of a P\&R system.

The study conducted by the authors is relevant for planning the P\&R system in medium-sized cities that already have this system or wish to implement it. The most important thing is to ensure connection to the public transport system and, in turn, provide incentives for private vehicle users to transfer to more sustainable modes of transport. One of the main criteria is public transport accessibility. However, to a more relevant extent, $P \& R$ should be reported to the authorities and become an essential tool for transport planning. In Latin America, $P \& R$ is relatively new. The same criteria should be used for local authorities and researchers who have already developed P\&R, and to compare Latin American and European cities.

\section{Conclusions}

The research conducted in this document establishes the criteria and sub-criteria that planning experts within the transportation field have considered in establishing a P\&R system. The selection of the order of importance of the criteria is performed through a multi-criteria decision model (MCDM). This new approach to the location of $P \& R$ facilities is possible because it integrates attributes such as environment, traffic and distance. The BWM's application allows us to discover, interpret, and know the experts' essential criteria in terms of locating a facility within the urban area of a city. Besides, the method contemplates a more precise selection than traditional MCDM models. The results of the models obtained are more reliable than those of the conventional models because the PCs are consistent.

The results using the BWM are more realistic than using traditional multi-criteria methods, reflecting mathematically the criteria taken into account by transportation planning experts. Thus, the most crucial criterion is the accessibility of public transportation. The public transport connections of a city should be connected to the P\&R system, thus ensuring a facility location that is close to public transport stations. In some Latin American cities, the P\&R system is completely new. Certain design parameters play a secondary role in the scientific verification of the parameters used to locate $P \& R$ 
systems. A new approach, for example, is to extend this technique to cities that already have a $P \& R$ system, and decide whether those criteria differ from the criteria of experts who already have experience in this field.

The model developed can be used to analyze various transport problems in cities of any size. The implementation of the BWM method has overcome the weakness of the AHP method. Nevertheless, the research process requires significant time and effort on the part of the evaluators, and thus the collection of answers from the different transportation planners interviewed may be difficult.

In future research, multiple MCDM techniques can be combined (e.g., ELECTREE, TOPSIS, machine learning), and the combination of this model with another broad model category, such as geographical and mathematical models, as well as optimization for the place of P\&R facilities, should be considered. A contrast between cities with P\&R systems and those that want to introduce them will shed light on new concepts. Conducting a study in which experts and potential users are interviewed will allow us to decide which criteria should be strengthened in the implementation and design of $P \& R$.

Author Contributions: Conceptualization, J.O. and S.M.; methodology, S.M.; software, J.O.; validation, S.M., J.O. and J.T.; formal analysis, S.M.; investigation, J.O.; resources, M.P.; data curation, J.P.; writing—original draft preparation, J.O.; writing-review and editing, J.O. and S.M.; visualization, J.P.; supervision, T.P. and J.T.; project administration, J.T.; funding acquisition, J.P. and M.P. All authors have read and agreed to the published version of the manuscript.

Funding: This research received no external funding.

Acknowledgments: We are more thankful to the Municipality of Cuenca for having the Sustainable Mobility Plan as well as the Universities that have collaborated in the development of this research.

Conflicts of Interest: The authors declare no conflict of interest.

\section{References}

1. Mozos-Blanco, M.Á.; Pozo-Menéndez, E.; Arce, R.; Baucells-Aletà, N. The way to sustainable mobility. A comparative analysis of sustainable mobility plans in Spain. Transp. Policy 2018, 72, 45-54. [CrossRef]

2. Diez, J.M.; Lopez-Lambas, M.E.; Gonzalo, H.; Rojo, M.; Garcia-Martinez, A. Methodology for assessing the cost effectiveness of Sustainable Urban Mobility Plans (SUMPs). The case of the city of Burgos. J. Transp. Geogr. 2018, 68, 22-30. [CrossRef]

3. Arsenio, E.; Martens, K.; di Ciommo, F. Sustainable urban mobility plans: Bridging climate change and equity targets? Res. Transp. Econ. 2016, 55, 30-39. [CrossRef]

4. Hoehne, C.; Chester, M.V. Greenhouse gas and air quality effects of auto first-last mile use with transit. Transp. Res. Part D Transp. Environ. 2017, 53, 306-320. [CrossRef]

5. Dell'Olio, L.; Cordera, R.; Ibeas, Á.; Barreda, R.; Oreña, B.A.; Moura, J.L. A methodology based on parking policy to promote sustainable mobility in college campuses. Transp. Policy 2019, 80, 148-156. [CrossRef]

6. Rizopoulos, D.; Esztergár-Kiss, D. A Method for the Optimization of Daily Activity Chains Including Electric Vehicles. Energies 2020, 13, 906. [CrossRef]

7. Antolín, G.; Ibeas, Á.; Alonso, B.; Dell'Olio, L. Modelling parking behaviour considering users heterogeneities. Transp. Policy 2018, 67, 23-30.

8. Nocera, S.; Pungillo, G.; Bruzzone, F. How to evaluate and plan the freight-passengers first-last mile. Transp. Policy 2020. [CrossRef]

9. Bruzzone, F.; Cavallaro, F.; Nocera, S. The integration of passenger and freight transport for first-last mile operations. Transp. Policy 2021, 100, 31-48. [CrossRef]

10. Saif, M.A.; Zefreh, M.M.; Török, Á. Public Transport Accessibility: A Literature Review. Period. Polytech. Transp. Eng. 2018, 47, 36-43. [CrossRef]

11. Chen, Z.; Xia, J.; Irawan, B.; Caulfied, C. Development of location-based services for recommending departure stations to park and ride users. Transp. Res. Part C Emerg. Technol. 2014, 48, 256-268. [CrossRef]

12. Chen, Z.; Xia, J.; Irawan, B. Development of Fuzzy Logic Forecast Models for Location-Based Parking Finding Services. Math. Probl. Eng. 2013, 2013, 1-6. [CrossRef] 
13. Chen, T.-C.T.; Honda, K.; Wang, Y.-C. Development of location-based services for recommending departure stations to park and ride users: A note. Int. J. Internet Manuf. Serv. 2015, 4, 54. [CrossRef]

14. Ortega, J.; Tóth, J.; Moslem, S.; Péter, T.; Duleba, S. An Integrated Approach of Analytic Hierarchy Process and Triangular Fuzzy Sets for Analyzing the Park-and-Ride Facility Location Problem. Symmetry 2020, 12, 1225. [CrossRef]

15. Ortega, J.; Tóth, J.; Péter, T. Mapping the Catchment Area of Park and Ride Facilities within Urban Environments. ISPRS Int. J. Geo-Informat. 2020, 9, 501. [CrossRef]

16. Ortega, J.; Hamadneh, J.; Esztergár-Kiss, D.; Tóth, J. Simulation of the Daily Activity Plans of Travelers Using the Park-and-Ride System and Autonomous Vehicles: Work and Shopping Trip Purposes. Appl. Sci. 2020, 10, 2912. [CrossRef]

17. Ortega, J.; Tóth, J.; Péter, T.; Moslem, S. An Integrated Model of Park-And-Ride Facilities for Sustainable Urban Mobility. Sustainability 2020, 12, 4631. [CrossRef]

18. Macioszek, E.; Kurek, A. The Use of a Park and Ride System-A Case Study Based on the City of Cracow (Poland). Energies 2020, 13, 3473. [CrossRef]

19. Buchari, E. Transportation Demand Management: A Park and Ride System to Reduce Congestion in Palembang City Indonesia. Proc. Eng. 2015, 125, 512-518. [CrossRef]

20. Shirgaokar, M.; Deakin, E. Study of park-and-ride facilities and their use in the San Francisco Bay Area of California. Transport. Res. Record 2005, 1927, 46-54. [CrossRef]

21. Ruan, J.-M.; Liu, B.; Wei, H.; Qu, Y.; Zhu, N.; Zhou, X. How Many and Where to Locate Parking Lots? A Space-time Accessibility-Maximization Modeling Framework for Special Event Traffic Management. Urban Rail Transit 2016, 2, 59-70. [CrossRef]

22. Balsa-Barreiro, J.; Valero-Mora, P.M.; Menéndez, M.; Mehmood, R. Extraction of Naturalistic Driving Patterns with Geographic Information Systems. Mob. Networks Appl. 2020, 1-17. [CrossRef]

23. Horner, M.W.; Grubesic, T.H. A GIS-based planning approach to locating urban rail terminals. Transportation 2001, 28, 55-77. [CrossRef]

24. Balsa-Barreiro, J.; Valero-Mora, P.M.; Berné, J.L.; Varela-García, F.-A. GIS Mapping of Driving Behavior Based on Naturalistic Driving Data. ISPRS Int. J. Geo-Informat. 2019, 8, 226. [CrossRef]

25. Farhan, B.; Murray, A.T. A GIS-Based Approach for Delineating Market Areas for Park and Ride Facilities. Trans. GIS 2005, 9, 91-108. [CrossRef]

26. He, B.; He, W.; He, M. The Attitude and Preference of Traveler to the Park \& Ride Facilities: A Case Study in Nanjing, China. Proc. Soc. Behav. Sci. 2012, 43, 294-301. [CrossRef]

27. Olaru, D.; Smith, B.; Xia, J.; Lin, T. (Grace) Travellers' Attitudes Towards Park-and-Ride (PnR) and Choice of PnR Station: Evidence from Perth, Western Australia. Proc. Soc. Behav. Sci. 2014, 162, 101-110. [CrossRef]

28. Cavadas, J.; Antunes, A.P. An optimization model for integrated transit-parking policy planning. Transportation 2019, 46, 1867-1891. [CrossRef]

29. Du, B.; Wang, D.Z. Continuum modeling of park-and-ride services considering travel time reliability and heterogeneous commuters-A linear complementarity system approach. Transp. Res. Part E Logist. Transp. Rev. 2014, 71, 58-81. [CrossRef]

30. Holguı́n-Veras, J.; Yushimito, W.F.; Aros-Vera, F.; Reilly, J.J. User rationality and optimal park-and-ride location under potential demand maximization. Transp. Res. Part B Methodol. 2012, 46, 949-970. [CrossRef]

31. Moslem, S.; Duleba, S. Application of AHP for evaluating passenger demand for public transport improvements in Mersin, Turkey. Pollack Period. 2018, 13, 67-76. [CrossRef]

32. Wong, J.K.W.; Li, H. Application of the analytic hierarchy process (AHP) in multi-criteria analysis of the selection of intelligent building systems. Build. Environ. 2008, 43, 108-125. [CrossRef]

33. de Brito, M.M.; Evers, M.; Almoradie, A.D.S. Participatory flood vulnerability assessment: A multi-criteria approach. Hydrol. Earth Syst. Sci. 2018, 22, 373-390. [CrossRef]

34. Duleba, S.; Moslem, S. Examining Pareto optimality in analytic hierarchy process on real Data: An application in public transport service development. Expert Syst. Appl. 2019, 116, 21-30. [CrossRef]

35. Hervás-Peralta, M.; Poveda-Reyes, S.; Prieto, G.D.M.; Santarremigia, F.E.; Pastor-Ferrando, J.P. Improving the Performance of Dry and Maritime Ports by Increasing Knowledge about the Most Relevant Functionalities of the Terminal Operating System (TOS). Sustainability 2019, 11, 1648. [CrossRef] 
36. Yüksel, I.; Dagdeviren, M. Using the analytic network process (ANP) in a SWOT analysis—A case study for a textile firm. Inf. Sci. 2007, 177, 3364-3382. [CrossRef]

37. Ergu, D.; Kou, G.; Shi, Y.; Shi, Y. Analytic network process in risk assessment and decision analysis. Comput. Oper. Res. 2014, 42, 58-74. [CrossRef]

38. Ligmann-Zielinska, A.; Jankowski, P. Spatially explicit integrated uncertainty and sensitivity analysis of criteria weights in multicriteria land suitability evaluation. Environ. Model. Softw. 2014, 57, $235-247$. [CrossRef]

39. Hsu, T.-H.; Pan, F.F. Application of Monte Carlo AHP in ranking dental quality attributes. Expert Syst. Appl. 2009, 36, 2310-2316. [CrossRef]

40. Yaraghi, N.; Tabesh, P.; Guan, P.; Zhuang, J. Comparison of AHP and Monte Carlo AHP Under Different Levels of Uncertainty. IEEE Trans. Eng. Manag. 2014, 62, 122-132. [CrossRef]

41. Bozóki, S.; Fülöp, J. Efficient weight vectors from pairwise comparison matrices. Eur. J. Oper. Res. 2018, 264, 419-427. [CrossRef]

42. Aydın, S.; Kahraman, C. Evaluation of firms applying to Malcolm Baldrige National Quality Award: A modified fuzzy AHP method. Complex Intell. Syst. 2018, 5, 53-63. [CrossRef]

43. Otto, K.N.; Hölttä-Otto, K. A multi-criteria assessment tool for screening preliminary product platform concepts. J. Intell. Manuf. 2007, 18, 59-75. [CrossRef]

44. Janssen, R. On the use of multi-criteria analysis in environmental impact assessment in the Netherlands. J. Multi-Criteria Decis. Anal. 2001, 10, 101-109. [CrossRef]

45. Zhu, K.-J.; Jing, Y.; Chang, D.-Y. A discussion on Extent Analysis Method and applications of fuzzy AHP. Eur. J. Oper. Res. 1999, 116, 450-456. [CrossRef]

46. Prasetyo, D.H.; Mohamad, J.; Fauzi, R. A GIS-based multi-criteria decision analysis approach for public school site selection in Surabaya, Indonesia. Geomatica 2018, 72, 69-84. [CrossRef]

47. Ghorbanzadeh, O.; Moslem, S.; Blaschke, T.; Duleba, S. Sustainable Urban Transport Planning Considering Different Stakeholder Groups by an Interval-AHP Decision Support Model. Sustainability 2018, 11, 9. [CrossRef]

48. Razandi, Y.; Pourghasemi, H.R.; Neisani, N.S.; Rahmati, O. Application of analytical hierarchy process, frequency ratio, and certainty factor models for groundwater potential mapping using GIS. Earth Sci. Informat. 2015, 8, 867-883. [CrossRef]

49. Lakusic, S.; Barauskas, A.; Mateckis, K.J.; Palevičius, V.; Antuchevičiene, J. Ranking conceptual locations for a park-and-ride parking lot using EDAS method. J. Croat. Assoc. Civ. Eng. 2018, 70, 975-983. [CrossRef]

50. Fierek, S.; Bieńczak, M.; Zmuda-Trzebiatowski, P. Multiple criteria evaluations of P\&R lots location. Transp. Res. Proc. 2020, 47, 489-496. [CrossRef]

51. Rezaei, J. Best-worst multi-criteria decision-making method: Some properties and a linear model. Omega 2016, 64, 126-130. [CrossRef]

52. Bozóki, S.; Fülöp, J.; Poesz, A. On reducing inconsistency of pairwise comparison matrices below an acceptance threshold. Central Eur. J. Oper. Res. 2015, 23, 849-866. [CrossRef]

53. Kumar, A.; Gupta, H. Evaluating green performance of the airports using hybrid BWM and VIKOR methodology. Tour. Manag. 2020, 76, 103941. [CrossRef]

54. Rezaei, J. Best-worst multi-criteria decision-making method. Omega 2015, 53, 49-57. [CrossRef]

55. Ren, J.; Liang, H.; Chan, F.T.S. Urban sewage sludge, sustainability, and transition for Eco-City: Multi-criteria sustainability assessment of technologies based on best-worst method. Technol. Forecast. Soc. Chang. 2017, 116, 29-39. [CrossRef]

56. Moslem, S.; Campisi, T.; Szmelter-Jarosz, A.; Duleba, S.; Nahiduzzaman, K.M.; Tesoriere, G. Best-Worst Method for Modelling Mobility Choice after COVID-19: Evidence from Italy. Sustainability 2020, 12, 6824. [CrossRef]

57. Orellana, D.; Guerrero, M.L. Exploring the influence of road network structure on the spatial behaviour of cyclists using crowdsourced data. Environ. Plan. B Urban Anal. City Sci. 2019, 46, 1314-1330. [CrossRef]

58. Hermida, C.; Cordero, M.; Orellana, D. Analysis of the influence of urban built environment on pedestrian flow in an intermediate-sized city in the Andes of Ecuador. Int. J. Sustain. Transp. 2019, 13, 777-787. [CrossRef] 
59. Ortega, J.; Tóth, J.; Péter, T. A Spatial Study of the Catchment Area of P\&R Facilities. In X International Conference on Transport Sciences Györ 2020; X International Conference on Transport Sciences: Győr, Hungary, 2020; p. 20. Available online: https://www.researchgate.net/publication/341978299_A_spatial_study_of_the_ catchment_area_of_PR_facilities (accessed on 12 March 2020).

60. Ortega, J.; Tóth, J.; Péter, T. Estimation of Parking Needs at Light Rail Transit System Stations. In Conference on Transport Sciences 2019; IX International Conference on Transport Sciences: Győr, Hungary, 2019; p. 8. Available online: https:/www.researchgate.net/publication/331976894_Estimation_of_parking_needs_at_ Light_Rail_Transit_System_stationsISBN_978-963-8121-85-1 (accessed on 30 April 2019).

Publisher's Note: MDPI stays neutral with regard to jurisdictional claims in published maps and institutional affiliations.

(C) 2020 by the authors. Licensee MDPI, Basel, Switzerland. This article is an open access article distributed under the terms and conditions of the Creative Commons Attribution (CC BY) license (http://creativecommons.org/licenses/by/4.0/). 